\title{
Resolving the Jeopardies of Consumer Demand: Revisiting Demarketing Concepts
}

\author{
Dr. Peggy E. Chaudhry* \\ Associate Professor of International Business \\ Villanova School of Business \\ 800 Lancaster Avenue \\ Villanova, PA 19085 \\ Phone: 610.519 .6442 \\ Fax: 610.519.6566 \\ peggy.chaudhry@villanova.edu \\ Dr. Ludovica Cesareo \\ Assistant Professor of Marketing \\ College of Business and Economics \\ Lehigh University \\ 621 Taylor Street \\ Bethlehem, PA 18015 \\ Phone: 610.758.2777 \\ lcesareo@lehigh.edu \\ Dr. Alberto Pastore \\ Professor of Management \\ Sapienza University of Rome \\ Via del Castro Laurenziano 9 \\ Rome, Italy 00161 \\ Phone: 390649766441 - 390649766264 \\ alberto.pastore@uniroma1.it \\ *Corresponding Author
}




\title{
Resolving the Jeopardies of Consumer Demand:
}

\author{
Revisiting Demarketing Concepts
}

\begin{abstract}
Demarketing is a way for managers to cope with excess and/or undesirable demand of their products or services. The situations that require ways to manage demand have changed and we revisit the original framework and modify the classification scheme of demarketing concepts introduced by Kotler and Levy in 1971 to reflect more contemporary issues. Previously, general demarketing topics addressed ways to curb excess demand due to temporary shortages, chronic overpopularity, and product elimination, all from a microenvironmental perspective - that is focusing on a firm's ability to changes its product/services to its customers and suppliers. We add macroenvironmental concepts of protective demarketing (e.g., government and social concerns related to preserving natural resources) and preventive demarketing (e.g., growing demographic rates of obesity that spur health concerns related to overconsumption). Formerly, selective demarketing addressed either undesirable or unprofitable consumption of the legitimate product/service. But, many firms across several sectors are fighting today against the undesirable consumption of illegitimate products/services, such as counterfeit and pirated goods - we thus introduce the notion of combative demarketing. We conducted personal interviews with experts across a variety of industries to provide insight into current demarketing tools. A discussion of demarketing with these stakeholders illustrates various measures that managers can employ to manage consumer demand, such as, using smaller packaging to reduce sugar/fat content, increasing the price of water, limiting visitor access to national parks, and educating consumers to identify counterfeit goods.
\end{abstract}

\section{Key Words}

Demarketing, Demand Management, Marketing Mix, Reduce Excess Demand, Undesirable Demand 


\section{DEMARKETING, YES, DEMARKETING TODAY}

Obesity is today's most challenging health issue, affecting nearly every family and community across the globe. It is a global societal problem which will take all of us working together and doing our part.

- Muhtar Kent, (former) CEO, the Coca-Cola Company ${ }^{a}$

The statement above is not from a non-governmental organization, watchdog group, political action committee, or health-care organization. The message comes from Muhtar Kent, the Chairman and former Chief Executive Officer of The Coca-Cola Company. Mr. Kent, and many executives across a multitude of industries, realize that the sustainability of their brands depends, today, on more than simply selling more products and services. Currently, the managerial focal point of demand maximizing strategies (e.g., building sales volume through a lower price; creating new products or services; providing free delivery of products) needs to incorporate demand management strategies by reducing excess demand and/or diminishing undesirable demand.

In 1971, Kotler and Levy proposed the concept of "demarketing" and addressed the need to better understand this aspect of demand management by stating: "Marketers have dealt with the problems of increasing demand for so long that they have overlooked a host of situations where the problem is to reduce demand or cope with inability to meet it" (p. 79). They presented a framework of demarketing that describes situations that would reduce excess demand (i.e., general demarketing); limit demand among a segment of customers that are unprofitable and/or undesirable (i.e., selective demarketing); and, devise perceived product shortages to lure additional consumers (i.e., ostensible demarketing). Given the novel demand management

\footnotetext{
${ }^{a}$ The Coca-Cola Company. (May 8, 2013). Coca-Cola announces global commitment to help fight obesity. Retrieved April 1, 2018, from https://www.coca-colacompany.com/press-center/press-releases/coca-cola-announcesglobal-commitments-to-help-fight-obesity
} 
challenges facing managers today, the objectives of this article center on: 1) exposing managers to the topic of demarketing; 2) revisiting the original framework and modifying the classification scheme of demarketing by adding distinct sub-categories; 3) discussing insights on demarketing through key informant interviews with various firms/agencies that include Coca-Cola, eBay, Estée Lauder, Louis Vuitton and the U.S. National Park Service; and, 4) providing a summary of demarketing solutions that leverage elements of the marketing mix. We first describe the distinct types of demarketing situations and include relevant examples, followed by a discussion of distinct demarketing issues suggested in the personal interviews. Then, we present a general summary of demarketing solutions to employ.

\section{NAVIGATING THE VARIETY OF DEMARKETING SITUATIONS}

General demarketing strategies are used to manage demand across various industry sectors (Lawther, Hastings, and Lowry 1997; Miklós-Thal and Zhang 2013). The alcoholic beverage industry and consumer advocates (e.g., Mother Against Drunk Driving-MADD) developed campaigns designed to reduce consumers' intake of alcohol and encourage consumers to drink responsibly, especially while driving a car. Various stakeholders are addressing sugar in processed foods and soft drinks that are linked with the rising health problems of obesity and diabetes (Colchero et al. 2016; Scammon et al. 2007). Companies and governmental agencies (e.g., US Department of Homeland Security) are designing ways to reduce the undesirable demand of counterfeit and pirated goods, such as movie piracy and counterfeit pharmaceuticals (Chaudhry, Cesareo \& Stumpf, 2014; Chaudhry and Stumpf, 2013; Cesareo \& Stöettinger, 2015). Both public officials and private agencies are addressing concerns of severe water shortages, making individuals rethink the price/value relationship of water-water is not 
"free" - as demand management policies are needed to safeguard this limited commodity (Guli, 2015; Kowitt, 2016). Table 1 illustrates the array of demarketing categories and sub-categories with an example of a product or service to illustrate each concept.

\section{[Insert Table 1 about here]}

Using this modified classification scheme allows managers to discriminate between different forms of demarketing circumstances, even if we acknowledge exceptions to this classification scheme. The idea of ostensible demarketing, for example, centers on portraying an image or physical environment that limits the amount of customers with the goal of making customers desire the product or service even more (imagine a small antiques store). This type of demarketing is the only category given in Kotler and Levy's original framework that does not fit into reducing excess and/or undesirable demand - thus, we have included this in our classification scheme in Table 1 for illustrative purposes only.

\subsection{General Demarketing—Coping with Excess Demand}

General demarketing refers to situations where sellers face excess demand for one or more of their products and/or services which require them to discourage consumers on either a temporary or permanent basis. Since motivations can be different, Kotler and Levy (1971) defined general demarketing as three distinct types: temporary shortages, chronic overpopularity, and product elimination. The two additional sub-categories we add to the classification scheme are protective and preventive demarketing that encompass challenges for the firm that have evolved from macroenvironmental concepts, external and uncontrollable elements of the business environment, such as, demographics, economic, socio-cultural, technological, ecological and political forces (DESTEP) (Claessens, 2015). Thus, protective demarketing concerns the limitation or reduction of the consumption of scarce/wasted natural resources such 
as water, gas, oil, or other raw materials and products. Preventive demarketing involves the limitation, or the promotion of a limited consumption of, potentially health-hazardous products, such as alcohol, tobacco, or foods high in sugar or fat. We further illustrate protective and preventive demarketing concepts in Sections 2.14 and 2.15, respectively.

\subsubsection{General Demarketing-Temporary Shortages}

When a company faces excess demand for its products/services which it cannot meet, either because the firm has underestimated demand, miscalculated production or both, that is what Kotler and Levy referred to as temporary shortages. For example, the Food and Drug Administration (FDA) claims that $65 \%$ of all drug shortages stem from problems related to manufacturing and quality issues (Kopcha 2016). To moderate this problem, the FDA expedites the approval process for generics, advocates the use of more advanced manufacturing, and created the Emerging Technology Team (ETT) to work together with manufacturers to streamline to adoption of new technologies in the manufacturing process.

The growing demand for Kentucky bourbon has made the Buffalo Trace Distillery, the owner of brands like Buffalo Trade, to deal with their supply shortages stemming from the fact that the bourbon must mature in oak barrels for eight to ten years. The company mitigates this situation by communicating to its customers that there will be temporary shortages, and that the company refuses to substantially increase price and/or reduce the age or proof of the whiskey to diminish demand. The firm is working on the supply side: increasing distillation and bottling lines, employing more people, and managing brands on allocation.

\subsubsection{General Demarketing-Chronic Overpopularity}

Chronic overpopularity refers to those instances in which a company wishes to reduce demand for one of its products/services, since it could lead to either a long-run decrease of its 
quality and customer satisfaction, and/or difficulty in managing unwanted demand. A typical example is the plight of popular tourist destinations. Condé Nast Traveler lists the top 15 destinations (e.g., Santorini, Norway, and Venice) that are developing measures to restrict access to their places due to the undesirable effects of an excessive amount of tourists on its environment and/or local populations (Largrave 2016). Farhad Manjoo of The New York Times reported on 'overtourism' in Europe (August 29, 2018) and described the situation as:

“...the most popular European destinations get stuffed to the gills with tourists, who outnumber locals by many multiples, turning hot spots into sweaty, selfiestick-clogged, "Disneyfied" towns."

This excess demand is caused by several trends, such as the global growth of more affluent consumers, the advent of low-cost airlines and larger cruise ships. But, the role of technologyfueled innovations, such as online booking, home-sharing (Airbnb) and social media (Facebook and Instagram) are also catapulting demand. Tourism experts assert that many visitors to iconic destinations are building a personal brand of the experience-where the photos taken on the trip and posted in social media are more important than the actual experience (Manjoo, 2018).

The CHERPLAN project, co-funded by the European Union, evaluated the need for sustainable tourism of cultural heritage sites in South Eastern Europe and advocates the use of demarketing when a site "loses its charm" for the visitors' experience due to chronic overpopularity. The analysts in this project propose several demarketing techniques that include: increasing the price of the service; creating a queuing system for visitors; limiting promotion to selected market segments; promoting the need to conserve the area through sustainable development; and diverting tourist traffic to alternative sites in the immediate area (Nared \& Viscović, 2014).

\subsubsection{General Demarketing_Product Elimination}


A company faces the decision to eliminate a product/service for multiple reasons that include low profitability, stagnant or declining sales volume or market share, costly maintenance of market share, risk of technological elimination, entering the mature or declining phase of the life cycle, and/or poor fit with business's strengths or declared mission (Avlonitis, 1985). But, managers must consider the impact on its customer that still desire or require that product/service. Kotler and Levy (1971) suggest three maneuvers to maintain customer goodwill during the phase-out of a product/service: 1) informing the consumer about the reasons why the product(s) is discontinued; 2) providing a form of compensation to the customers; and, 3) sustaining some type of minimal level of inventory to wean your most loyal customers. The financial sector has been moving towards the elimination of paper checks and US consumers are encouraged to use alternative payment mechanisms such as online banking, e-wallets, and mobile app transfers (e.g., Venmo). The financial incentives to eliminate paper checks are clear-the Association of Financial Professionals estimates the median cost of using a check is $\$ 3$ compared to 30 cents for an electronic transaction (Roberts, 2017).

\subsubsection{General Demarketing-Protective}

While the original specification of general demarketing took a micro-environmental perspective (discussing how to limit excess demand for a specific product/service), we take a more macro-environmental perspective, adding the sub-category of protective demarketing in order to include one of the most challenging issues of limiting excess demand for scarce natural resources. One could argue that 'chronic overpopularity' could be used to describe the excess consumption of a natural resource, such as oil. But, this type of 'general demarketing' was originally conceived to address two situations where: 1) the quality of the product/service was endangered by excess demand - such as overcrowding of tourist destinations; and/or 2) a 
situation where management cannot appease excess demand-such as the constraint of limited seating at a restaurant. Preserving scarce environmental resources through sustainable development has evolved as a serious issue over the past 30 years as production and consumption have skyrocketed (Olsen, Slotegraaf \& Chandukala, 2014). Even Kotler suggested that "one generation can exploit the existing resources-oil, water, timber, fish - so intensely that the next generation is doomed to accept a lower standard of living" (2017, p.4). We thus introduce the macro-environmental concept of "protective general demarketing," which refers to all those strategies employed by various stakeholders in order to limit consumption, or waste, of scarce natural resources, such as water, gas, oil, or other raw materials and products.

Gnepa (2007) did introduce the linkages between raising consumer awareness to facilitate water conservation in drought-prone areas of California, and recommended that consumer education to decrease demand using demarketing techniques was a viable alternative to solve the problem. The overall recommendation of this study centered on solutions that included increasing the price of water and educating consumers regarding both their consumption of water for indoor and outdoor use. Researchers in the State of Palestine surveyed consumers in the Gaza Strip to garner their perspective of demarketing water and established that creating an awareness of both the economic and social benefits of conserving water were the most important (Salem et al., 2018). In order to curb undesirable demand, multiple companies have launched a variety of awareness campaigns. For example, Thirst, a non-profit organization, is taking action to build awareness of the looming water crisis. Mina Guli, CEO of Thirst, commented (September 22, 2015):

"Millennials are one of the most influential consumer groups in the world. They have a combined purchasing power of $\$ 2.45$ trillion, but $90 \%$ of them don't even know there is a water crisis." 
The world sales of passenger cars was 79.02 million in 2017 with a projection of 81.6 million units expected to sell in 2018 (Statista(a), 2018). Growing markets, such as China, have quadrupled sales from 6.76 million units in 2008 to 24.72 million units in 2017 (Statista (b), 2018). Jude Clemente in Forbes reported that U.S. gasoline consumption in 2017 represents 10\% of all global oil consumption and there has been an uptick in demand since 2012 and thus questions the idea of an 'electric car revolution' in the U.S. to solve our insatiable appetite for oil (Clemente, 2017). There needs to be a significant shift in consumer attitudes towards automobiles and their personal usage patterns — such as increasing the purchase of electric cars and using alternative transportation (e.g., car-sharing through Zipcars). In 2018, the Volvo XC40 crossover SUV became the company's first all-electric car and the firm is appealing to consumers using the slogan "Our future is electric - a new chapter in our story". In 2019, the Swedish firm will offer all of its 2019 models as either hybrid, plug-in hybrid, or battery electric options. Other automakers, such as Acura, Audi, Honda, Hyundai, and Mitsubishi are aggressively marketing electric SUV cross overs to appeal to consumers also. Overall, the overconsumption of a natural resource is unsustainable and must be curbed through future demarketing.

\subsubsection{General Demarketing-Preventive}

Persuading consumers to reduce demand for the so-called 'vice' products, such as alcohol and highly-processed, sugar-laden foods, continues to be a conundrum. The general demarketing sub-category of 'product elimination' or 'temporary shortages' does not explain this type of deconsumption. Alcoholic beverages and sugar used in drinks and processed food will continue to exist into the foreseeable future - the goal is to curb excess demand for preventive reasons, such as detrimental health stemming from excessive sugar consumption. Thus, 'preventive general 
demarketing' signifies those strategies employed by manufacturers, policy-makers, and other stakeholders to reduce, or promote the limited consumption of, health-hazardous products, such as alcohol, tobacco (Yang et al., 2013), and sugar (Reis et al., 2017). The campaigns of getting consumers to reduce their intake of alcohol (Scammon, Mayer \& Smith, 1991) have been studied for decades, mainly under the genre of social marketing (for example, see Andreasen, 1994; Kotler et al., 2002; Lee and Kotler, 2016). This overconsumption of vice products can lead to tragic consequences for which the producers can be blamed. Companies are facing shifts in the macroenvironment, such as political forces, and many countries, such as Hong Kong, Hungary, Mexico and the U.K., and cities within the United States, such as Philadelphia, have either passed or are debating whether to implement a sugar tax to curb the growth of obesity in the local population. In fact, a publication in the British Medical Journal asserts that a $10 \%$ tax on sugar-sweetened drinks in Mexico caused a 12\% reduction in sales (Colchero et al., 2016).

The United Kingdom government continues to address the de-consumption of sugar in young consumers through education at its "Change4Life" campaign (www.nhs.uk/change4life). Companies have started to tackle this issue by modifying their brand strategies, such as Coca Cola, offering its brand of low-calorie products (i.e., Diet Coke, Coke Zero, and Coca-Cola Life). Similarly, snack brands (from cereal bars to nuts) have introduced "100 calorie" minipackets to provide single-serve, reduced calorie packaging as an effective way to reduce excessive caloric intake and obesity, especially among children (Sothern, 2004). Previous studies have established the need to stem both cigarette (Chauhan \& Setia, 2016) and alcohol consumption (Wall, 2005) for health and safety reasons using demarketing campaigns. The "Alcohol. Think Again" campaign in Australia employs a variety of messages, such as "Drunk people don't think straight" to curb the problems related to overconsumption of alcoholic 
products.

\subsection{Selective Demarketing-Dealing with Undesirable Demand}

Kotler and Levy (1971) envisioned "selective demarketing" as the strategies employed by a company to discourage either an unprofitable and/or undesirable consumer segment under the premise that a firm could not legally deny sales to this type of customer. They described the problem of 'hippies' staying at luxury hotels and not projecting the right image in the hotel's lobby and restaurants to their more traditional patrons-middle-aged conservatives. Farquhar and Robson (2017) further define this type of demarketing as "a strategic option for a firm to manage customers who are or are likely to be a poor fit with its offering" (p. 165). The concept of "place demarketing" uses market segmentation to attract an optimal tourist to its destination (Medway et al., 2011). Like the concept of "chronic overpopularity," more tourists may not be the ideal situation, but this form of demarketing centers on attracting the 'right type of customer' to reinforce the quality of the consumption experience. Through the idea of selective demarketing, destinations such as the Galápagos Islands have been selectively targeting a certain type of consumer to its ecotourism destination (Largave, 2015).

\subsubsection{Selective Demarketing—Combative}

We have added a sub-category to selective demarketing, "combative demarketing," to explain tactics designed by a company to deter the undesirable demand of counterfeit products, such as fake pharmaceuticals (Chaudhry \& Stumpf 2013), and pirated digital goods, such as online movie piracy (Chaudhry, Cesareo \& Stumpf 2014). Globalization and the rise of the Internet (Chaudhry, 2017b) have fostered the proliferation of illicit suppliers of products for which original manufacturers must curtail this undesirable demand-consumers are complicit and willing to obtain counterfeits and pirated products (Chaudhry, 2017a). Oxford Economics, in 
its 2018 study "Combatting Illicit Trade: Consumer Motivations and Stakeholder Perspectives", surveyed 37,000 consumers across 37 European countries to ascertain the likelihood that consumers knowingly purchased illicit products (e.g., cigarettes and clothing). The analysts found that $27 \%$ of these consumers reported their purchases being possibly illicit, and another $11 \%$ were confident that their purchases were illicit products. In general, this study revealed significant levels of undesirable demand for fake cigarettes, alcohol, films, clothing and medicines (Oxford Economics, 2018, pp 10-11). No industry is immune to counterfeiting and piracy: anything from fashion apparel to children's toys, pharmaceuticals to movies, cigarettes to computer software is readily available in fake versions at a fraction of the original's cost, both offline and online.

In 2017, the US Department of Homeland Security (DHS) reported that the total number of intellectual property right border enforcement actions increased by $12 \%$ compared to 2016 (U.S. Department of Homeland Security, 2017, p. 3). Today, the border enforcement officials at the DHS must face the monumental task of scrutinizing over 11 million maritime containers at seaports, 10 million containers arriving by truck and 3 million by rail annually. Additionally, the growth of e-commerce has exploded and an estimated 260 million packages were shipped into the US via postal and express carriers in 2017-intercepting counterfeits has become an enormous undertaking and the agency recently established the e-Commerce and Small Business Branch to combat counterfeits in e-commerce shipments (US Department of Homeland Security, 2017, pp. 2 and 8). For fiscal year 2017, the DHS reported seizures of counterfeits in wearing apparel (15\% of all cases), watches/jewelry (13\%) footwear (12\%), consumer electronics (12\%), consumer products (11\%), handbags/wallets (10\%), pharmaceuticals/personal care (6\%), optical media $(2 \%)$, computers/accessories $(1 \%)$, toys $(1 \%)$, and all other $(15 \%)$ with a total value of 
\$1.206 billion (US Department of Homeland Security, 2017, p. 9). Bear in mind that these data metrics are understated since only a small fraction of all products shipped into the US will be scrutinized by border enforcement officials - thus, firms must employ ways to curtail the continued growth of illicit trade (Chaudhry and Cesareo, 2017).

The notion of combative demarketing has been used to describe various anticounterfeiting campaigns designed to decrease the undesirable demand for illicit goods, such as counterfeit pharmaceutical or pirated music and movies (Chaudhry and Cesareo, 2017; Chaudhry and Stumpf, 2013). A few studies have assessed anti-counterfeiting campaigns as demarketing maneuvers and recommend demand-side remedies to battle the consumption of illicit goods, such as using fear of legal prosecution (i.e., rendering more tangible the legal consequences of purchasing a counterfeit/pirated good), employing role models to denounce piracy (i.e., Jackie Chan and Arnold Schwarznegger's "Mission to Stop Piracy" public awareness campaign in Asia), creating linkages to organized crime (i.e., making consumers aware of the involvement of criminal organizations profiting from worldwide counterfeit trade), employing social norming (peer pressure) (i.e., especially in collectivistic cultures, like China, Vietnam or Taiwan, where loss of face due to counterfeiting could threaten social relationships), and educating consumers (i.e., via awareness-building campaigns on the negative consequences of purchasing counterfeit products) (Chaudhry \& Cesareo, 2017).

\section{REVISITING MANAGERIAL TOOLS TO DEMARKET}

The research for this article was conducted in three phases. The first phase looked at a review of the existing literature on demarketing and a search for current examples of demarketing problems in the media and trade publications to provide pragmatic examples of each type of demarketing (refer back to Table 1). In the second phase, structured interview 
questions were developed and key informant interviews were conducted with 7 firms (Barilla, Coca-Cola, eBay, Estée Lauder, Johnson \& Johnson, Louis Vuitton, Peroni), 3 managers of the U.S. National Park Service (NPS) in two separate locations (i.e., Yellowstone and Denali National Parks), and 2 water-experts in academia (from the University of Colorado at Boulder and Villanova University). These participants were vetted and selected based on their knowledge of demarketing topics. Most interviews were conducted on the telephone. Following a brief introduction, the experts were asked about how and when their company had strategically faced excess or unwanted demand, as well as how those strategic choices were implemented. We used the framework developed by Cullwick (1975) to develop questions for our structured interview to ascertain how the firm (agency) altered its product, price, place, and/or promotion to ration or reduce demand of their products and/or services. The final phase of the research involved thematic analysis (Braun and Clark, 2006), by which we reviewed the interview transcripts for insightful themes of how firms (agencies) reduce and/or ration demand, and what levers in the marketing mix (product (service), price, place and promotion) are used to demarket the product or service.

We acknowledge that this study has limitations due to its small sample size and the bias of the interviewees. While many of the demarketing examples may be generalizable beyond the key sectors studied, this should not be assumed. Secondly, although all key informants had extensive professional experience addressing demarketing, a degree of subjectivity is unavoidable. For this reason, suggestions developed as a result of these interviews should be interpreted as the key informant's unique perspective on the subject, as opposed to unbiased testament. In addition, we had to rely on our own desk-research to supplement the interview data to provide a broad-spectrum of demarketing solutions. We succinctly summarize our findings 
based on these interviews per the classification scheme provided in Table 1 (Gerstner, Hess, \& Chu, 1993). However, we acknowledge that there are demarketing situations that were not mentioned in these managerial narratives, such as temporary shortages, and provide a comprehensive summary of demarketing mix solutions in Table 2.

\subsection{General Demarketing--Chronic Overpopularity}

To create more exclusivity for their luxury brand, the managers at Louis Vuitton implicitly demarket their signature product by increasing the price of the entry-level Monogram canvas bag, the "Speedy", once they realized this product was becoming too popular and widespread in the younger segments of the population. The manager at Louis Vuitton describes this situation as:

"Some luxury brands have diluted their brands too far down to give a broader set of consumers' access to luxury. Now though, they have realized the difficulties in maintaining the signaling value of their core, luxury brand, and are demarketing the lower lines (e.g. Marc by Marc Jacobs), in order to re-give prestige to their core, higher-end brands."

When the product is a destination, such as a National Park, a manager can be struggling with excess demand through chronic overpopularity. A visitor in a National Park is expecting a consumption experience that includes picturesque scenery, wildlife sightings, and seclusion—not an array of tour buses, gridlock traffic, and long ques of tourists attempting to take a pristine photo of a geyser. One manager at Denali National Park (Alaska) commented on devising ways to maintain the 'wilderness character' of the park's natural beauty — to sustain a:

"Feeling of solitude; a sensation of being in a pristine environment; viewing wolves and/or bears; being away from noise; and having unconfined recreation." 
All managers that we interviewed from the NPS discussed that the agency is starting to conduct surveys with tourists to find better ways to preserve the quality of the consumption experience. Specifically, managers at the NPS in both Denali and Yellowstone National Park are addressing ways to alleviate overtourism in these iconic tourist destinations. For example, one manager at Denali National Park summarized her view of balancing the increased demand while preserving the place of consumption as:

"Public lands operate in intimate economics. National Parks may be in themselves objects: bounded landscapes that can be (with difficulty) reduced or enlarged. But the true commodity of public lands is connection: a shared place to remedy human wants and needs today and in the future. That is what we aim to do: balance the recreational use of these lands and harvesting for traditional livelihoods without degrading the intrinsic value of place. We deal in intimacy and practicality at once, maintaining human connection to a place, and preserving discrete resources."

Overall, the managers at the NPS are balancing excess demand knowing that other stakeholder interests in the surrounding communities, such as hotels and restaurants, rely on the tourism as a major source of revenue. A manager at the Yellowstone National Park summarized this dilemma as:

"It's not easy to limit the access; but if we go through all of the research and it shows that we need to limit visitations to protect the resources of Yellowstone National Park, will we have the political will to do that knowing that these parks are economic drivers for the states of Montana, Wyoming and Idaho?"

But, a solution may reside in diverting tourists to nearby destinations to alleviate overtourism.

One manager at the NPS commented on efforts to preserve the natural environment of the park by diverting the volume of tourists to attractions near the boundaries of the park, such as activities at lodges, restaurants, and other events to attract tourists to other locations.

Not all companies and agencies have the ability to alter their price to control demand in situations of chronic overpopularity. A few managers in the public sector struggled with using 
price as a key demarketing tactic. For example, the managers interviewed at both Denali and Yellowstone National Parks consistently reinforced that this place destination was supposed to be affordable to the public —a 'parks for all' sense of accessibility — and thus the agency was very sensitive to employing price as a demarketing tool. A national park official described the situation as:

"Our entry fees are controlled by law ...the Senate just approved changing a lifetime pass from $\$ 10$ to $\$ 80 \ldots$ we have very little discretion on price and have to go through a public process ... even changes of prices for tours/buses to use in the park is a two-year process ... we cannot survive on entrance fees ... it cost $\$ 90$ million to operate the park last year and we collected \$14 million in entrance fees."

A change in price must be sanctioned by the Interior Department of the U.S. and the proposed price change of tripling entrance fees for 17 of the most visited National Parks resulted in a public outcry. Thus, Interior Secretary Ryan Zinke conceded a smaller increased admission fee for all 117 fee-charging parks (Rott 2018). Ironically, this attempt to appease the national public will do little to alleviate the National Parks plagued with chronic overpopularity, such as Yellowstone.

\subsection{General Demarketing--Product Elimination}

The Johnson \& Johnson manager described how the firm demarkets their product by physically eliminating it from the marketplace, either due to stocking issues or because the company itself is launching a competitive and better product. As Kotler and Levy originally suggested (1971), the firm, for example, withdrew its Dentosan mouthwash to give space to its newly acquired brand, Listerine, letting consumers know of the "new and improved" product. The manager at Johnson \& Johnson stated: 
"When a company launches a new "hero" product, it demarkets the old product lines, since all the support needs to be focused on the new, better and improved product."

Furthermore, the manager at Estée Lauder remarked on the continuous cycle in the cosmetics industry to constantly innovate brands in order to meet consumer demands while keeping some inventory in alternative channels for the most loyal customers. The cosmetic leader remarked:

"We are constantly faced with the challenge of making sure that the inventory is as productive as possible for the retailers; that means, for some brands we are constantly phasing out products that are not as desirable for consumers and/or cyclical from a fashion standpoint. We are always discontinuing and introducing new products for the consumer. We are constantly replacing colors, and we discontinue them because of demand and fashion issues."

These managerial narratives are perfect examples of product elimination in order to market another novel product - this type of demarketing is at the very center of a firm's business acumen.

\subsection{General Demarketing--Protective}

If a product is a scarce resource, such as water, excess demand can be countered by starting to provide different types of the product for various consumption purposes. For example, the water that is used in the home to flush a toilet, run the dishwasher, and for drinking is coming from the same source. A water-expert interviewed from the University of Colorado at Boulder (CU Boulder) commented on the irony of this situation:

"We need more understanding of usage patterns ... 98\% of the water that we use, such as to wash a car, does not need water from the tap . . . we have to create a dual system ... more cities are using green roofs to catch storm water for toilet flushing."

Overall, the CU Boulder water consultant elaborated on ways to re-distribute water used in offices, such as harvesting techniques to capture rain water for consumption and elaborated: 
"More cities like San Francisco are harvesting storm water via so-called rain gardens and green roofs on top of office buildings. Some office buildings are developing their own on-site water recycling programs to treat something like 'black water' [wastewater from toilets]."

In January 2018, Salesforce Tower in San Francisco announced that it would be the largest inhouse water recycling program in the United States. The 'blackwater' system to be installed in this high-rise commercial building will be the first collaborative effort between a city government (San Francisco), the owner of a building, and its tenant to support this type of sustainability program (Flynn, 2018). The city of San Francisco is at the forefront of educating consumers about the value of 'rainwater harvesting' to preserve water and has programs in place to give discounts on both rain barrels and larger capacity cisterns to reduce the consumption of drinking water by providing alternative sources of supply (Rainwater Harvesting, 2018).

There can be multiple ways use price to address excess consumption of scarce resources that go beyond simply raising the price. The water-expert interviewed at Villanova University (VU) used a tiered-pricing model to limit demand in a local community water project in Madagascar as simply described implementation as:

"A price structure consisted of a tiered-system based on consumption in the local community. So, a flat fee to access the water, then two subsequent thresholds based on the volume of consumption."

The CU Boulder water conservationist echoed this type of pricing model in the interview and suggested, "the more you use the more you pay based on a conservation schedule ... but we need to figure out what consumers will respond to since pricing may not even be on their list."

In general, consumers in the U.S. have been given access to water at a low-price for several decades and other measures, such as 'social norming', are going to be the key means to 
limit consumption of this resource in the future. The CU Boulder water-expert candidly described his viewpoint on using peer pressure as:

"We have usually focused on the supply of water-but understanding the nature of demand and controlling it is a key driver for the future. There is a demographic and cultural component to minimizing demand. In the past, we used 'guilt' to deter environmental behaviors. But, I think we are moving to 'social norming' people in the U.S. will be more motivated to consume less water through peer pressure and possibly remuneration for less consumption."

\subsection{General Demarketing--Preventive}

All of the managers working in the beverage and food industry confirmed their efforts to reduce consumption through modifications to the product — mainly through the decreased size of the packaging or lessening the 'vice' ingredient, such as sugar, saturated fat, or alcohol content. The manager at Coca-Cola emphasized that his firm has launched 'mini' versions of their signature drinks in order to decrease the caloric intake for their customers and launched campaigns, such as its "New Perfectly Small Can", to educate consumers. Peroni, well-known for its premium lager, has employed both smaller packaging $(25 \mathrm{ml})$ and lowered alcohol content to demarket some of its products. The manager at Peroni commented that "to foster responsible drinking, we created smaller format Nastro Azzurro beers, or Peroncino beers, which contain a lower level of alcohol". The manager at Barilla, the manufacturer of food products like pasta, Mulino Bianco and Baiocchi cookies, reinforces this demarketing in the food and beverage industry by enthusiastically stating:

"We have tremendously reduced the amount of saturated fats and sugars in our cookies, for example, because we know the importance of a healthier and more balanced lifestyle."

Peroni carries out training programs for distribution partners in order for them to know when to forbid or stop the sale of beer, either to minors or people who have already consumed 
too much alcohol, thus helping the fight against illicit consumption and drunk driving. The manager at Peroni commented:

"Selling beer, there are specific groups of the population to whom we cannot market at all (minors/children). There are occasions though when even towards our regular, legal customers, we need to demarket our product if it represents a hazard to their safety or health. We call it "responsible consumption," for example when drinking before driving. We want to make sure that the sale and consumption of our goods is responsible, that is why we carry out training programs with our distribution partners in order for them to know when to stop selling our product."

The manager at Peroni reiterated that the firm would continue to create campaigns to foster responsible drinking and consumption to decrease alcohol intake and discourage drunk driving. The food and beverage industry has launched campaigns to promote healthier lifestyles and educate consumers about nutrition. The executive at Barilla described the company's "Less volume, more value" theme often communicated to consumers.

Coca-Cola expanded its "Taste the Feeling" (2016) campaign to include the promotion of a $250 \mathrm{ml}$ bottle with the tagline of "A Little Can Be Just Right" to offer the product in much smaller quantities to target health-conscious consumers (Coca-Cola launches mini bottle with multimillion-dollar push, 2016). Guido Barilla, Chairman of the Barilla Group, was directly asked by the Italian press as to whether a processed-food item like cookies should have health warnings on the packaging similar to cigarette packaging. Surprisingly, Guido Barilla responded "yes" and proclaimed that he supported this type of labelling on packages if this type of information would help consumers better understand the need to follow a more balanced diet. The manager at Barilla reiterates this point below:

"Our biggest message is always promoting a healthier lifestyle, which means eating well and feeling well. Obesity and overweightness are two huge issues of our modern society, and we strive to communicate eating not necessarily less, but 
better. We also communicate all nutritional values on our packaging, to make sure consumers are fully informed of what they are eating."

Likewise, the manager at Peroni confirms the value of these campaigns as:

"Promotion is our strongest lever, since we use the packaging itself to foster the responsible consumption of alcohol. We also create ad hoc communication campaigns, also in collaboration with industry associations, in order to remind consumers to drink responsibly (e.g., no drinking during pregnancy, no drinking and driving). These initiatives are the most successful, since they are trying to change the culture we live in."

\subsection{Selective Demarketing}

The executive at Estee Lauder gave an in-depth narrative of the transformation of the company's Prescriptives brand and the decision in 2010 to move the product from retail distribution to online sales only. This top-level executive stated:

"We have close working relationships with our retail partners and have had them for many years. One of the key concerns we had when we decided to shut the brand down was: How do we go to our retail partners and say thank you for supporting this brand for the last 20-plus years, but we have decided it's no longer worthy of that support?"

Overall, in the Prescriptives case, this leading cosmetic firm had to manage demarketing the brand in its main channel—retail space — while at the same time providing a replacement product for this space to appease the stores that represent its legitimate physical channel. The firm also offered to buy-back $100 \%$ of the retails stores' inventory of the Prescriptives products.

\subsection{Selective Demarkering--Combative}

In the fight against counterfeits, no tactic is left unexplored. Brands are continuously modifying and innovating their products in order to make them harder to duplicate and deter counterfeiters, while also adding unique identifiers to the authentic goods (i.e. QR codes, smart

packaging, and holograms). Price has been used as one of the main product cues to determine 
whether a product is fake-if the consumer pays $\$ 100$ for a Rolex watch in an offline market (such as a souk for tourists in Dubai) or online marketplace (such as eBay), the consumer should know the product is counterfeit. The manager at eBay commented that many brand owners are trying to enforce a "minimum-priced advertising" (MAP) for their authorized sellers in this online marketplace. But, the manager also reveals the quagmire of eBay's VeRO (Verified Rights Owner) program to monitor price as:

"The MAP and distribution contracts between authorized sellers and the brand owners is not something eBay can intervene on ... the reason is that eBay can find pretty much any type of item, from handbags sold at a very high price to sellers offering it at a lower price because they simply want to get rid of the item. So, we might find this as suspicion of counterfeiting, but not as a definitive answer of 'this is fake'.

The manager also acknowledged that the illicit traders may sell at the same price, or even a higher price, to deceive the consumer about the authenticity of the product, making the identification of a fake a much harder process.

Distribution-wise, Louis Vuitton tightens the physical distribution of originals-leading towards an absolutely exclusively-owned model — in order to avoid the penetration of illicit goods in their legitimate distribution channels, and monitors online marketplaces. The manager at eBay described how this company screens its e-commerce marketplace and suspends suspicious sellers through its VeRO reporting tool as:

"eBay's policy is to prevent users from creating a new account once they have been suspended ... there is a dedicated team that would look at the information provided when they register and our system might even block the creation of an account right away. In addition, the reporting tool (VeRo) gives brand owners the opportunity to flag a specific account to eBay and an investigative team will look into it and take the necessary actions."

Promotion-wise, luxury companies have created campaigns against counterfeits to stress the quality-related and artisanal aspects of originals. The manager at Louis Vuitton states: 
"As luxury marketers, our main focus is to communicate and sell the luxury 'dream'." That doesn't mean though we are not proactive against counterfeits, and we do what we can, internally and externally, to fight against them and raise awareness among consumers."

The manager at eBay stressed in the interview that "[T]he key point is building the relationship with the brands and working together to eradicate counterfeits." Given the fact that demand management is linked to the buyers'/consumers' awareness, the negative outcomes of consuming illicit products, such as obtaining a computer virus from illegal video-streaming, must be reinforced with consumers via educational and awareness-building initiatives.

\section{SUMMARY OF DEMARKETING AND CONCLUDING REMARKS}

In terms of demarketing through product measures, the managers discussed a variety of tactics that include developing smaller packaging in the food industry to decrease consumption, eliminating the product line or service to support new trends in the cosmetic industry, educating consumers on suitable usage patterns for water, and preserving the consumption experience of place destinations. Price is the principal and most obvious tactic used to demarket a product or service - thus the notion of "increasing the price to limit demand" is not a revelation. But, other themes that emerged in the interviews include raising the price to build even more exclusivity in luxury goods; creating tiered-price regimes to conserve natural resources, conceding the inability to raise price in a public good, such as national parks, and monitoring price discrepancies to detect illicit goods sold in online marketplaces.

In terms of distribution and place, several companies and agencies interviewed are working on controlling access to the distribution of the product/service and place destination, especially in situations of overcrowding in national parks to ease overtourism. Managers candidly discussed building effective relationships with distributors to limit the consumption of 
alcohol, move the product to a different sales platform to make retail space available for new products, monitor the internet for illicit goods, and to plan novel ways to distribute and conserve natural resources. Several managers suggest using promotional tactics to implement principal demarketing initiatives that include changing the image of the consumption of food and beverages to support a healthier lifestyle, raising consumer awareness of the consequences of the overconsumption of scarce resources, developing campaigns to use peer pressure to decrease demand for both natural resources and counterfeit/pirated goods, and empowering consumers to engage in sustainable remedies to protect limited natural resources. Overall, the managers clearly asserted that promotion is much more than just advertising, and that it includes an assortment of demarketing tools, both offline and online, that employ a variety of media platforms. For example, the NPS would like to use social media apps to alert visitors of places in the park that are experiencing high-levels of congestion to address overtourism in areas such as the geysers in Yellowstone.

Consumers oftentimes want to help companies and be part of the solution when a problem arises. In the case of counterfeit goods, that could mean setting up consumer hotlines or dedicated webpages where informed consumers can report spotting fakes, both offline and online, thus curtailing the offer of such illicit goods. In the case of scarce resources, like oil, communicating the importance of gradually moving toward more sustainable resources, like solar, wind, or hydro power, can make consumers want to behave more sustainably. Companies like SolarCity are giving incentives to consumers to install solar panels in their homes, not only providing them with cleaner, sustainable energy but also rewarding them for giving back excess energy to the grid. 
Table 2 summarizes several key demarketing recommendations for practitioners within the context of using the elements of the marketing mix (product, price, place, promotion) to decrease excess and/or undesirable demand. Many of these suggestions were given in the personal interviews; others, were uncovered in our desk-research on the topic. Overall, we believe that this summary will be a useful guideline for managers working in a variety of sectors to reflect on distinct demarketing solutions to tackle customer demand.

\section{[Insert Table 2 about here]}

This article has revisited the original work of Kotler and Levy (1971) on demarketing to create a better understanding of how firms use demarketing to manage either excess or undesirable demand of their products and services in terms of microenvironmental (e.g., suppliers, customers, competition) and/or macroenvironmetal forces (e.g., demographic, natural/physical). Companies can eliminate an entire product line to introduce a better product, change prices of their signature products to make sure that only the 'right' customers purchase them; tighten distribution and train their partners to make sure they know when, and to whom, to sell the products; and, finally, they can communicate, through integrated marketing communication campaigns to all their stakeholders about the benefits and potential drawbacks of using their products. Overall, we believe that the continued study of demand management strategies to influence consumer demand in different states of availability of the product or service is a promising area for future research.

\section{REFERENCES}

Alcohol. Think Again. (n.d.) Retrieved June 15, 2018, from http://alcoholthinkagain.com.au/Campaigns

Andreasen, A. (1994). Social marketing: Its definition and domain. Journal of Public Policy \& Marketing, 13(1), 108-114.

Avlonitis, G. J. (1985). Product elimination decision making: does formality matter? The Journal of Marketing, 49(1), 41-52. 
Braun, V. \& Clarke, V. (2006). Using thematic analysis in psychology. Qualitative Research in Psychology, 3(2), 77-101.

Cesareo, L. \& Stoëttinger, B. (2015). United we stand, divided we fall: How firms can engage consumers in their fight against counterfeits. Business Horizons, 58(5), 527-537.

Change4Life. (n.d.). Retrieved June 15, 2018 from https://www.nhs.uk/change4life

Chaudhry, P.E. (2017a). Handbook of Research on Counterfeiting and Illicit Trade. Cheltenham, UK: Edward Elgar Publishing.

Chaudhry, P.E. (2017b). The looming shadow of illicit trade on the internet. Business Horizons $60(1), 77-89$.

Chaudhry, P.E. \& Cesareo, L. (2017). Fake and pirated: Do consumers care? Journal of Business Strategy, 38(6), 11-19.

Chaudhry, P.E., Cesareo, L. \& Stumpf, S. (2014). What influences rampant movie piracy? Journal of Management Systems, 24(4), 73-95.

Chaudhry, P.E. \& Stumpf, S. (2013). The challenge of curbing counterfeit prescription drug growth: Preventing the perfect storm. Business Horizons, 56(2), 189-192.

Chauhan, H., \& Setia, P. (2016). Discouraging cigarette smoking through de-marketing strategies. Future Business Journal, 2(1), 31-39.

Claessens, M. (2015). The macro environment - six forces in the environment of business. Retrieved November 1, 2018, from https://marketing-insider.eu/macro-environment/

Clemente, J. (2017, December 21). 3 oil charts to close 2017. Retrieved May 4, 2018, from https://www.forbes.com/sites/judeclemente/2017/12/21/three-oil-charts-to-close2017/\#6ebb3bcd18d6

Coca-cola launches mini bottle with multi-million-dollar push. (2016, October 7). Retrieved June 18, 2018, from http://www.adnews.com.au/coca-cola-launches-mini-bottle

Colchero, M. A, Popkin, B.M., Rivera, J.A., \& Ng, S.W. (2016). Beverage purchases from stores in Mexico under the excise tax on sugar sweetened beverages: Observational study. British Medical Journal, 352. Retrieved September 10, 2016, from http://www.bmj.com/content/352/bmj.h6704

Cullwick, D. (1975). Positioning demarketing strategy. Journal of Marketing, 39(2), 51-57.

Demand for bourbon outpaces supply. (2013, May 22). Retrieved August 10, 2017, from https://www.fsrmagazine.com/content/demand-bourbon-outpaces-supply

Farquhar, J. \& Robson, J. (2017). Selective demarketing: When customers destroy value. Marketing Theory, 17(2), 165-182.

Flynn, P. (2018, January 11). A new sustainability milestone: Innovative water recycling system in salesforce tower. Retrieved August 31, 2018, from

https://www.salesforce.com/blog/2018/01/salesforce-tower-innovative-water-recyclingsystem.html

Gerstner, E., Hess, J. \& Chu, W. (1993). Demarketing as a differentiation strategy. Marketing Letters, 4(1), 49-57.

Gnepa, T. (2007). Consumer awareness and successful demarketing of public goods: A study of residential water conservation behavior. Journal of Academy of Business and Economics. Retrieved September 10. 2016, from http://www.freepatentsonline.com/article/JournalAcademy-Business-Economics/172010688.html

Guli, M. (2015, September 22). Why business needs to get serious about water scarcity. World Economic Forum. Retrieved August 30, 2018 from 
https://www.weforum.org/agenda/2015/09/why-business-needs-to-get-serious-about-waterscarcity/

Kopcha, M. (2016, February 1). Modernizing pharmaceutical manufacturing to improve drug quality: Ensuring a safe and adequate supply of drugs. Retrieved August 10, 2017, from http://blogs.fda.gov/fdavoice/index.php/tag/drug-shortages/

Kotler, P. \& Levy, S. (1971). Demarketing, yes, demarketing. Harvard Business Review, 49(6), 74-80.

Kotler, P. (2017, August 25). Welcome to the age of demarketing. Retrieved April 17, 2018, from http://www.marketingjournal.org/welcome-to-the-age-of-demarketing-an-excerpt-fromphilip-kotlers-autobiography-philip-kotler/

Kotler, P., Roberto, N., \& Lee, N.R. (2002). Social Marketing: Improving the Quality of Life. Thousand Oaks, California: Sage Publications.

Kowitt, B. (2016, May 17). Why we should stop calling California's water shortage a drought. Retrieved September 9, 2017, from http://fortune.com/2016/05/17/california-water-shortagedrought/

Largrave, K. (2016, October 24). 15 places telling tourists to stay home. Retrieved April 30, 2018, from https://www.cntraveler.com/galleries/2015-06-19/barcelona-bhutan-places-thatlimit-tourist-numbers

Lawther, S., Hastings, G. \& Lowry, R. (1997). De-marketing: Putting Kotler and Levy's ideas into practice. Journal of Marketing Management, 13(4), 315-325

Lee, N. R. \& Kotler, P. (2016). Social marketing: Changing behaviors for good. Thousand Oaks, California: Sage Publications.

Manjoo, F. (2018, August 29). 'Overtourism' worries Europe. How much did technology help get us there? The New York Times. Retrieved September 4, 2018, from https://www.nytimes.com/2018/08/29/technology/technology-overtourism-europe.html

Medway, D., Warnaby, G. \& Dharni, S. (2011). Demarketing places: rationales and strategies. Journal of Marketing Management, 27(1-2), 124-142.

Miklós-Thal, J. \& Zhang, J. (2013). (De)Marketing to manage consumer quality inferences. Journal of Marketing, 50(1), 55-69.

Moye, Jay. (2018, May 8). Share a coke and share the summer: 2018 campaign focuses on special moments. Retrieved August 31, 2018, from https://www.cocacolacompany.com/stories/share-a-coke-and-share-the-summer-2018-campaign-focuses-onspecial-moments

Nared, J. \& Viscović, N. (2014). Managing cultural heritage sites in southeastern Europe. Ljubljana, Slovenia: ZRCSAZU (Scientific Research Center Slovenian Academy of Science).

National Park Service. (2017). Yellowstone national park visitors from 1904-2017. Retrieved May 3, 2018, from https://irma.nps.gov/Stats/SSRSReports/Park\%20Specific\%20Reports/Annual\%20Park\%20R ecreation\%20Visitation\%20(1904\%20-\%20Last\%20Calendar\%20Year)?Park=YELL

Olsen, M. C., Slotegraaf, R. J., \& Chandukala, S. R. (2014). Green claims and message frames: How green new products change brand attitude. Journal of Marketing, 78(5), 119-137.

Oxford Economics. (2018). Combatting illicit trade: Consumer motivations and stakeholder perspectives'. Retrieved July 14, 2018, from https://www.oxfordeconomics.com/thoughtleadership/combatting-illicit-trade 
Rainwater Harvesting. (2018). Retrieved August, 31, 2018, from https://www.sfwater.org/index.aspx?page $=178$

Reis, F., Alcaire, F., Deliza, R., Ares, G. (2017). The role of information on consumer sensory, hedonic and wellbeing perception of sugar-reduced products: Case study with orange/pomegranate juice. Food Quality and Preference, 62, 227-236.

Roberts, K. (2017, July 26). Why can't Americans ditch checks? Retrieved May 5, 2018, from https://www.bloomberg.com/news/articles/2017-07-26/why-can-t-americans-give-up-paperchecks

Rott, N. (2018). National park service to 'modestly' raise entrance fees in plan to cut repair backlog. Retrieved August 27, 2018, from https://www.npr.org/2018/04/13/601980212/national-park-service-to-modestly-raiseentrance-fees-in-plan-to-cut-repair-back

Salem, M., Baidoun, S., Almuzaini, R. (2018). Water consumption demarketing strategies with reference to the Gaza Strip, Palestine. Polish Journal of Environmental Studies, 27(1), 297304.

Scammon D.L., Mayer R.N., \& Smith K.R. (1991). Alcohol Warnings: How do you know when you have had one too many. Journal of Public Policy \& Marketing, 10(1), 214-218.

Sothern, M. S. (2004). Obesity prevention in children: physical activity and nutrition. Nutrition, 20(7), 704-708.

Statista. (2018(a)). Passenger and commercial vehicle sales in China from 2008 to 2018 (in million units). Retrieved May 1, 2018, from https://www.statista.com/statistics/233743/vehicle-sales-in-china/

Statista. (2018(b)). Number of cars sold worldwide from 1990 to 2018 (in million units). Retrieved May 1, 2018, from https://www.statista.com/statistics/200002/international-carsales-since-1990/

Stumpf, S., Chaudhry, P., Perretta, L. (2011). Fake: can business stanch the flow of counterfeit products? Journal of Business Strategy, 32(2), 4-11.

The Coca-Cola Company. (2013, May 8). Coca-Cola announces global commitments to help fight obesity. Retrieved August 9, 2017, from http://www.coca-colacompany.com/presscenter/press-releases/coca-cola-announces-global-commitments-to-help-fight-obesity

US Department of Homeland Security. (2017). Intellectual property rights seizure statistics fiscal year 2017. Retrieved November 1, 2018, from https://www.cbp.gov/sites/default/files/assets/documents/2018-Apr/ipr-seizure-statsfy2017.pdf

Wall, A. (2005). Government demarketing: Different approaches and mixed messages. European Journal of Marketing, 39(5/6), 421-427.

Yang, Z., Schaninger, C., \& Laroche, M. (2013). Demarketing teen tobacco and alcohol use: Negative peer influence and longitudinal roles of parenting and self-esteem. Journal of Business Research, 66(4), 559-567. 


\section{Table 1. Classification of Demarketing}

\begin{tabular}{|c|c|c|}
\hline \multicolumn{2}{|c|}{ 1. General Demarketing } & \multirow[t]{2}{*}{ Authorship } \\
\hline Sub-Category & Example & \\
\hline $\begin{array}{l}\text { Temporary Shortages-situations } \\
\text { that create unexpected excess demand } \\
\text { for the product/service due to } \\
\text { inaccurate forecasting of consumer } \\
\text { demand, problems with production, } \\
\text { or both. }\end{array}$ & $\begin{array}{l}\text { Pharmaceutical shortages (e.g., intravenous "IV" bag } \\
\text { shortage due to Hurricane Maria's } 2017 \text { devastation of } \\
\text { production facilities located in Puerto Rico). }\end{array}$ & Kotler \& Levy, 1971 \\
\hline $\begin{array}{l}\text { Protective-devise ways to limit } \\
\text { excess consumption, or waste, of a } \\
\text { scarce natural resource, such as water } \\
\text { or oil, to safeguard limited supply of } \\
\text { the product for future consumption. }\end{array}$ & $\begin{array}{l}\text { Rain harvesting (e.g., San Francisco's Water Power } \\
\text { Sewer service is educating consumers to capture storm } \\
\text { water through rainwater barrels to use in the } \\
\text { home/office for other purposes, in order to preserve the } \\
\text { consumption of drinking water). }\end{array}$ & Revised, new model, 2018 \\
\hline $\begin{array}{l}\text { Preventive-creates ways to reduce, } \\
\text { or the promotion of a limited } \\
\text { consumption of, potentially health- } \\
\text { hazardous products, such as alcohol, } \\
\text { tobacco, or sugar to prevent diseases } \\
\text { linked to overconsumption, such as } \\
\text { obesity, diabetes, liver and lung } \\
\text { cancer. }\end{array}$ & $\begin{array}{l}\text { Smaller packaging of food and beverage products } \\
\text { (e.g., Coca-Cola's offering of smaller versions ( } 7.5 \\
\text { ounces) of its regular-sized bottles/cans ( } 12 \text { ounces). } \\
\text { The } 2018 \text { "Share a Coke and Share the Summer" } \\
\text { campaign allows consumer to buy personalized } 8 \text { ounce } \\
\text { bottles online with two lines of text, such as "Taylor } \\
2018 \text { "). }\end{array}$ & Revised, new model, 2018 \\
\hline Sub-Category & Example & \\
\hline $\begin{array}{l}\text { Selective - discourages either an } \\
\text { unprofitable and/or undesirable } \\
\text { consumer segment for the legitimate } \\
\text { offering of a product/service. }\end{array}$ & $\begin{array}{l}\text { Eco-tourism (e.g., destinations such as the Galápagos } \\
\text { Islands go beyond reducing the numbers of tourists to } \\
\text { its destination and selectively target a certain type of } \\
\text { eco-tourist to reinforce the consumption experience). }\end{array}$ & Kotler \& Levy, 1971 \\
\hline $\begin{array}{l}\text { Combative-- tackles the problem of } \\
\text { undesirable consumer demand when } \\
\text { illegitimate forms of supply } \\
\text { (counterfeits, pirated digital goods) of } \\
\text { the product/service is readily } \\
\text { available for consumption. }\end{array}$ & $\begin{array}{l}\text { Counterfeit goods (e.g., Louis Vuitton battling the } \\
\text { widespread availability of counterfeit handbags and } \\
\text { wallets sold in offline and online marketplaces). }\end{array}$ & Revised, new model, 2018 \\
\hline \multicolumn{3}{|c|}{ 3. Ostensible Demarketing } \\
\hline $\begin{array}{l}\text { Ostensible - portrays an image } \\
\text { and/or physical environment that } \\
\text { limits the amount of customers with } \\
\text { the goal of making consumers desire } \\
\text { the product or service even more. }\end{array}$ & $\begin{array}{l}\text { Exclusive restaurants (e.g., a three Michelin stars sushi } \\
\text { restaurant in London that limits seating to nine persons) }\end{array}$ & Kotler \& Levy, 1971 \\
\hline
\end{tabular}


Table 2: Summary of Demarketing Mix Solutions

\begin{tabular}{|c|c|c|c|c|}
\hline \multicolumn{5}{|c|}{ General Demarketing } \\
\hline & Product & Price & Distribution & Promotion \\
\hline $\begin{array}{l}\text { Temporary } \\
\text { Shortages }\end{array}$ & $\begin{array}{l}\text {--Assess the geographic risks } \\
\text { (e.g., natural disasters) of } \\
\text { limited manufacturing sites. } \\
\text {--Create better analytical tools to } \\
\text { forecast demand. }\end{array}$ & $\begin{array}{l}\text {--Avoid price-gouging due to } \\
\text { limited inventory. } \\
\text {--Offer discounts to loyal } \\
\text { customers once inventory stocks } \\
\text { have been replenished. }\end{array}$ & $\begin{array}{l}\text {--Inform channel members on } \\
\text { plans to deal with the shortages. } \\
\text {--Devise an equitable plan to } \\
\text { distribute limited inventory. }\end{array}$ & $\begin{array}{l}\text {--Notify about shortages and } \\
\text { time frame for expected stock } \\
\text { replenishment. } \\
\text {--Reduce promotion } \\
\text { expenditures temporarily. }\end{array}$ \\
\hline $\begin{array}{l}\text { Chronic } \\
\text { Overpopularity }\end{array}$ & $\begin{array}{l}\text {--Establish complimentary/ } \\
\text { comparable services near the } \\
\text { place destination to divert } \\
\text { demand. } \\
\text {--Devise a plan to maintain } \\
\text { quality of the consumption } \\
\text { experience in place destination. }\end{array}$ & $\begin{array}{l}\text {--Increase the price for all } \\
\text { visitors to limit demand. } \\
\text {--Create tiered-pricing to reflect } \\
\text { different prices based on peak } \\
\text { demand periods. }\end{array}$ & $\begin{array}{l}\text {--Limit access to the place } \\
\text { destination (timed-entry; quotas } \\
\text { on visitors). } \\
\text {--Cap the number of } \\
\text { products/services sold at one } \\
\text { time. }\end{array}$ & $\begin{array}{l}\text {-- Communicate overcrowding } \\
\text { via social media apps. } \\
\text {--Advertise incentives for } \\
\text { consumers to visit during off- } \\
\text { peak periods. }\end{array}$ \\
\hline $\begin{array}{l}\text { Product } \\
\text { Elimination }\end{array}$ & $\begin{array}{l}\text {--Design new products that } \\
\text { validate the need to discontinue } \\
\text { the older product/service. } \\
\text {--Monitor technological } \\
\text { advances that justify the need } \\
\text { for the new product or service. }\end{array}$ & $\begin{array}{l}\text {--Lower price to decrease } \\
\text { inventory of discontinued } \\
\text { product. } \\
\text {--Offer price incentives to switch } \\
\text { to the new product. }\end{array}$ & $\begin{array}{l}\text {--Change market access for the } \\
\text { remaining inventory (e.g. move } \\
\text { from offline to online distribution } \\
\text { only). } \\
\text {--Retain limited stock to slowly } \\
\text { wean some customers to the new } \\
\text { product/service. } \\
\text {--Maintain good relationships } \\
\text { with retail by guaranteeing } \\
\text { purchase back of old inventory } \\
\text { and supply (shelf-space) of the } \\
\text { new one. }\end{array}$ & $\begin{array}{l}\text {--Alert consumers about the } \\
\text { future elimination of the } \\
\text { product/service to maintain } \\
\text { goodwill. } \\
\text {--Provide information about the } \\
\text { improved benefits of the new } \\
\text { product/service. }\end{array}$ \\
\hline Protective & $\begin{array}{l}\text {--Analyze the generic use of the } \\
\text { product (e.g., tap water for all } \\
\text { uses in the home) and develop } \\
\text { multiple ways to segment the } \\
\text { use of the scarce resource (e.g., } \\
\text { harvesting storm water). } \\
\text {--Increase the perceived value of } \\
\text { the resource 'today' by } \\
\text { reinforcing the expected changes }\end{array}$ & $\begin{array}{l}\text {--Increase the price to reflect the } \\
\text { real value of the resource. } \\
\text {--Create two-tiered systems of } \\
\text { price based on consumption of } \\
\text { the resource to reward } \\
\text { conservation. }\end{array}$ & $\begin{array}{l}\text {--Limit the distribution of the } \\
\text { resource during peak periods of } \\
\text { consumption. } \\
\text {--Create innovative ways to re- } \\
\text { distribute the scarce resource } \\
\text { (e.g., in-house water recycling } \\
\text { programs in offices) and supply } \\
\text { more sustainable alternatives to } \\
\text { the resource (e.g., solar power vs. }\end{array}$ & $\begin{array}{l}\text {--Create personal messages to } \\
\text { describe the negative effect that } \\
\text { scarcity of the resource will } \\
\text { have on individual consumption. } \\
\text {--Empower the consumer to be } \\
\text { part of the solution that } \\
\text { preserves and/or harvests the } \\
\text { natural resource. }\end{array}$ \\
\hline
\end{tabular}




\begin{tabular}{|c|c|c|c|c|}
\hline & $\begin{array}{l}\text { in availability for the near future } \\
\text { ("sustainable development"). }\end{array}$ & & oil). & \\
\hline Preventive & $\begin{array}{l}\text {--Create new product concepts } \\
\text { (e.g." single-serving") to limit } \\
\text { consumption } \\
\text {--Decrease or change the } \\
\text { harmful ingredients, such as } \\
\text { sugar, to gradually shift } \\
\text { consumer taste preferences. }\end{array}$ & $\begin{array}{l}\text {--Increase the price to limit the } \\
\text { demand of product. } \\
\text {--Create a real reward for } \\
\text { consuming less by offering price } \\
\text { trade-offs that reinforce a } \\
\text { monetary incentive for } \\
\text { purchasing smaller versions of } \\
\text { the product. }\end{array}$ & $\begin{array}{l}\text {--Decrease the distribution of } \\
\text { product to effectively limit its } \\
\text { supply. } \\
\text {--Limit the availability of places } \\
\text { that allow consumption of the } \\
\text { product. }\end{array}$ & $\begin{array}{l}\text {--Educate using social norming } \\
\text { tactics to portray acceptable } \\
\text { levels of consumption. } \\
\text {--Inform consumers regarding } \\
\text { the nutritional values/caloric } \\
\text { intakes and its potential health } \\
\text { hazards. } \\
\text {--Offer health programs to } \\
\text { reward conscious consumption. }\end{array}$ \\
\hline \multicolumn{5}{|c|}{ Selective Demarketing } \\
\hline & Product & Price & Distribution & Promotion \\
\hline Selective & $\begin{array}{l}\text {--Provide limited service to the } \\
\text { undesirable market segment. } \\
\text {--Create tiered loyalty groups to } \\
\text { attract the coveted market } \\
\text { segment. }\end{array}$ & $\begin{array}{l}\text {--Use price discrimination to } \\
\text { discourage the undesirable } \\
\text { consumer (within legal } \\
\text { constraints). } \\
\text {--Create price/loyalty rewards to } \\
\text { attract the market segment. }\end{array}$ & $\begin{array}{l}\text {--Locate the service in areas that } \\
\text { have close geographic proximity } \\
\text { to the desired consumer. } \\
\text {--Provide exclusive access to the } \\
\text { product or service to the targeted } \\
\text { clientele. }\end{array}$ & $\begin{array}{l}\text {--Selective promotion through } \\
\text { advertising channels. } \\
\text {--Promote images of 'ideal } \\
\text { customers' that reinforce } \\
\text { affinity to the product/service. }\end{array}$ \\
\hline Combative & $\begin{array}{l}\text {--Add unique identifiers to the } \\
\text { product that allow consumers } \\
\text { and channel members to } \\
\text { authenticate (e.g., scanning QR } \\
\text { codes on packaging using a } \\
\text { smartphone). } \\
\text {--Design novel packaging } \\
\text { and/or product attributes that are } \\
\text { difficult and costly for the illicit } \\
\text { traders to duplicate (e.g., } \\
\text { invisible tags behind labels on } \\
\text { packaging). }\end{array}$ & $\begin{array}{l}\text {--Rethink price (by creating sub- } \\
\text { brands or tiered prices) to the } \\
\text { point where consumers become } \\
\text { indifferent to the lure of cheaper } \\
\text { illegitimate products/services. } \\
\text {--Investigate the price of } \\
\text { illegitimate products - the sellers } \\
\text { of illicit products may be } \\
\text { matching or charging a higher } \\
\text { price to deceive the consumer } \\
\text { and authorized channel members. }\end{array}$ & $\begin{array}{l}\text {--Create distribution of licit } \\
\text { digital products that provide } \\
\text { "anytime/anywhere" access (e.g., } \\
\text { music streaming services). } \\
\text {--Monitor legitimate channels for } \\
\text { the infiltration of counterfeit and } \\
\text { pirated goods (e.g., selective } \\
\text { distribution) - illicit products are } \\
\text { not just sold at illegitimate } \\
\text { places. }\end{array}$ & $\begin{array}{l}\text {--Educate consumers on the } \\
\text { sellers of illicit goods, e.g. } \\
\text { establishing credible linkages to } \\
\text { organized crime. } \\
\text {--Develop personal messages to } \\
\text { reduce demand (e.g., a fear of } \\
\text { getting a computer virus from } \\
\text { illegal downloads). }\end{array}$ \\
\hline
\end{tabular}




\section{Response to Reviewer 1}

We greatly appreciate the time that you have taken to provide even further constructive feedback on how to improve the manuscript. Below is a list of revisions per your suggestions (our responses in italics)

First, a remaining gap is the lack of information provided regarding the data collection and analysis process. More details then "reviewing" the transcript would be needed to assess the rigor of the research, although I recognize that this journal is more practitioner-oriented.

- We did add a new section to clarify the analysis of the interview transcripts after the first review of the paper to comply with the other reviewer's comments regarding this point. But, we thank you for pointing this out to us in the third revision of the manuscript. To further clarify, we did follow Braun and Clarke's (2006) approach to thematic analysis to provide excerpts from the interview transcripts, but as you suggested above, we did not provide further details of this content analysis given the managerial orientation of the paper and thus we decided not to provide further academic details of this type of qualitative analysis. We have added the reference to Braun and Clarke's (2006) work to the current version of the manuscript to be more precise about the research method we adopted.

Second, section 3 set out to provide new tools to demarket. As noted in the last review, linking the proposed strategies, such as those related to the table, to the summary text is needed. For example, some Section 3 sub-sections, as written now, did not offer any strategies. For Product Elimination, it is not clear what measures they can take in regards to the elimination of products other than to just eliminate products. For the Combative subsection, it is not clear what measures managers can take to combat counterfeit/pirated goods - it explicitly states that the measures described do not work (e.g., regarding pricing controls). However, it does not then actually provide specific measures. What did the mangers suggest? It seems the summary on page 24 listed some things and the table had a number of suggestions. While I agree with you that the table is useful, I would suggest more of links between the table and the text, as now there seems to be a major disconnect, especially in some sections.

- Thank you for this comment. We have enriched the product elimination section (referring the readers back to Kotler and Levy's original suggestions) and clarified the combative strategies (at all levels of the marketing mix) further.

Third, and more minor, the example about Barilla on page 19-20 doesn't fit with the definition of preventive marketing, which was given as "limited consumption of, health-hazardous products, such as alcohol, tobacco" - that example seems to focus on not necessarily limiting consumption, but rather changing the product attributes regarding ingredients - fats and sugar.

- Thank you for this comment. We have slightly modified the definition of preventive to include the limitation of over-consumption of health-hazardous products that are high in sugar or fat. Thus, the ways in which this limitation can be implemented do include modifying the product or packaging in order to reduce the health risks associated with consumption. 
Additional issues - Citations

There were numerous citation issues throughout the text. For example, citation issues that need attending to include:

"Farhad Manjoo of The New York Times reported on 'overtourism' in Europe and described the situation as: "...the most popular European destinations get stuffed to the gills with tourists, who outnumber locals by many multiples, turning hot spots into sweaty, selfie-stickclogged, "Disneyfied" towns (2018, August 29, ๆ5).”

- Thank you for this comment. The full citation with active weblink can be found in the references.

"For example, Thirst, a non-profit organization, is taking action to build awareness of the looming water crisis. Mina Guli, CEO of Thirst, commented (2015, p. 3): "Millennials are one of the most influential consumer groups in the world. They have a combined purchasing power of $\$ 2.45$ trillion, but $90 \%$ of them don't even know there is a water crisis."'

- Thank you for this comment. The full citation with active weblink can be found in the references.

$\square$ "The world sales of passenger cars was 79.02 million in 2017 with a projection of 81.6 million units expected to sell in 2018 (Statista(b), 2018). Growing markets, such as China, have quadrupled sales from 6.76 million units in 2008 to 24.72 million units in 2017 (Statista(a), 2018)."

- Thank you for this comment. We have reversed the two citations to correctly be A before $B$. The full citations with active web-links can be found in the references.

"The "Alcohol.Think Again" campaign in Australia employs a variety of messages, such as "Drunk people don't think straight" to curb the problems related to overconsumption of alcoholic products (alcoholthinkagain.com.au/Campaigns)"

- Thank you for this comment. We have deleted the weblink from the text and left it in the references section.

"Oxford Economics, in its study on Combatting Illicit Trade: Consumer Motivations and Stakeholder Perspectives, surveyed 37,000 consumers across 37 European countries to ascertain the likelihood that consumers knowingly purchased illicit products (e.g., cigarettes and clothing)."

- Thank you for this comment. We have added the year in text and the full citation with active web-link can be found in the references. 
"In 2017, the US Department of Homeland Security (DHS) reported that the total number of intellectual property right border enforcement actions increased by $12 \%$ compared to 2016 (U.S. Department of Homeland Security, 2017, p.)" - check form

- Thank you for this comment. We have added the missing page number to the in-text quote. The full citation with active web-link can be found in the references.

"intercepting counterfeits has become an enormous undertaking and the agency recently established the e-Commerce and Small Business Branch to combat counterfeits in e-commerce shipments (DHS, 2017, pp. 2 and 8).”

- Thank you for this comment. We have written out the full source in text (US Department of Homeland Security) wherever it was necessary. The full citation with active web-link can be found in the references.

Page. 12 - missing commas e.g.: "“...continued growth of illicit trade (Chaudhry and Cesareo 2017).” Plus a few more on page 13.

- Thank you for this comment. We have added the missing commas where necessary.

Additional issues - Other smaller grammar/wording issues:

There seems to be extra spaces between sentences in first paragraph of page 9 .

- Thank you for this comment. We have double checked the entire document for extra spaces.

"hippies" likely does not need to be in quotations, as it is a word in the dictionary. If you would rather it stand out, than single quotes may be more appropriate. Same for "vice" and "mini" on page 19.

- $\quad$ Thank you for this comment. We have made the necessary changes.

Page 11- Seems to be a missing word: "The analysts found that $27 \%$ of these consumers reported purchases were possibly illicit..."

- Thank you for this comment. We have re-worded that phrase.

Page 13- missing bracket: (i.e., rendering more tangible the legal consequences of purchasing a counterfeit/pirated good), employing role models to denounce piracy (i.e., Jackie Chan and Arnold Schwarznegger's “Mission to Stop Piracy” public awareness campaign in Asia).

- $\quad$ Thank you for this comment. All brackets are now in place. 